\title{
DIVERSITY OF INDUCED M1V4 MUTANT POPULATION OF CASSAVA (MAHINOT ESCULANTA CRANTZ)
}

\author{
Kinyua M.G ${ }^{1 *}$ and H. Okwaro ${ }^{2}$ \\ ${ }^{* 1,2}$ University of Eldoret
}

*Corresponding Author:

\begin{abstract}
: -
Cassava owns a small genome (about $770 \mathrm{Mb}$ ), it is considered as an allopolyploid with a high level of heterozygosity characteristics which severely hamper the speed and ease of introgressing useful genes in cassava. Mutation techniques form a classical procedure of development of variation in crops like cassava while genetic markers can be used to reveal genetic variation in the germplasm. This study was undertaken to determine the genetic relatedness of mutagenised cassava early generation populations through phenotypic and genetic marker procedures. Diversity of mutagenised population of cassava at MIV4 generation was examined at seedling stage in the greenhouse and at adult stage in the field through checking phenotypic and genetic traits. Plant height, number of lobes on leaves, petiole colour, number of nodes per stem and gel separation of PCR products developed from SSR markers differed significantly between selected putative mutants as well as in comparison with parent line. For example, plant height of the 10 selected mutants ranged from $16 \mathrm{~cm}$ to $113 \mathrm{~cm}$ where the parent grew to $24.33 \mathrm{~cm}$ while the number of nodes ranged from 11 to 24 with the parent having 13 nodes. Diversity of the mutant lines was demonstrated and further studies can be undertaken to quantify the variation for breeding and production of cassava.
\end{abstract}

Key words: -cassava; induced mutation; diversity; SSR markers 


\section{INTRODUCTION}

Breeding goals of yield increases, root quality improvement, and disease resistance in cassava are considerably slowed down by biological characteristics of the crop, which includes a long growth cycle, a heterozygous genetic background and a poor knowledge of the organization of crop diversity. These factors severely hamper the speed and ease of introgressing useful genes in cassava. The consequences are that cassava production fails to keep up with demand, especially in regions where over $90 \%$ of yield is consumed as food, leading to an increase in acreage of cassava fields mostly into marginal lands (Kariuki et al., 2002).

Mutation techniques form a classical procedure of development of variation in crops like cassava (Kinyua and Okwaro, 2021). Cassava is planted using 7-30 cm portions of the mature stem as propagules. The selection of healthy, diseasefree and pest-free propagules is essential. The stem cuttings are sometimes referred to as 'stakes'.

Cassava (Manihot esculenta Crantz) is in the Spurge family, Euphorbiaceae; the castor bean and castor oil are also in this family and is classified in the species M. esculenta. It is the only one of 98 species in its family that is widely cultivated for food production. It is a tetraploid, heterozygous dicotyledonous plant with $(2 n=4 x=36$ chromosomes (Nassar, 1978) and is the main form that is utilized; other ploidy levels are not utilized, but have been produced experimentally. Cassava owns a small genome (about $770 \mathrm{Mb}$ ), it is considered as an allopolyploid with a high level of heterozygosity. Cassava is a hardy plant that can survive in poor soils which are low in soil fertility, and they relatively produce higher yields than other tuber and root crops (Temegne et al. 2015). However, cassava genotypes respond differently to diverse environmental conditions (soil, climate) and biotic factors (Dixon et al. 2002).

Genetic markers are used to evaluate genetic divergence in a breeding population (Andrade et al. 2017). Molecular markers can be used to reveal genetic variation in germplasm collection. These markers include isozymes markers, restriction fragment polymorphism (RFLP) and PCR (Polymerase Chain Reaction) based makers (William et al.1990).

\section{Advantages of SSR markers}

The SSR markers have the following advantages over other markers namely; Low quantities of DNA template required (10-100 ug per reaction), they have high genomic abundance, they are randomly distributed throughout the genome, they show high levels of polymorphism (alleles), their band profiles can be interpreted in terms of loci and alleles, have Co dominant alleles, their allele sizes can be determined with an accuracy of single base pairs, allowing accurate comparison across different gels, are highly reproducible and are amenable to automation. This makes them suitable to study polymorphism among cassava which is highly heterozygous. This study was initiated to determine the genetic relatedness of mutagenised cassava early generation populations through phenotypic and genetic marker procedures.

\section{MATERIALS AND METHODS \\ Phenotypic analysis \\ Study site}

The Initiation of material for tissue culture was done in tissue culture laboratory at the National Plant breeding research centre Njoro (N.P.B.R.C). The centre lies at Latitude $\mathrm{O}^{0} 20^{\prime}$ south and longitude $35^{\circ} 56^{\prime}$ East. It stands at an altitude of $2160 \mathrm{~m}$ ASL. Green house studies were done at Egerton University's Horticultural green house. Egerton University lies at approximately latitudeO ${ }^{0} 23^{\prime}$ south and longitude $35^{0} 35^{\prime}$ East at mean altitude of $2200 \mathrm{~m}$ above sea level. These two sites are in the central Rift Valley in Kenya.

Field evaluation was done at KALRO Regional Research Centre Parkerra. Parkerra lies at approximately latitude 0.28.3'N and longitude $35.59 .8^{\prime}$ Eat mean altitude $1067 \mathrm{~m}$ above sea level. The soils at the experimental site are fluvisol. The average annual rainfall at Perkerra totalled $654 \mathrm{~mm}$ with weak bimodal peaks recorded from March-May and June-August. Annual evapo-transpiration totalled $1360 \mathrm{~mm}$ and exceeded rainfall every month of the year by as low as $19 \mathrm{~mm}$ in May and as high as $109 \mathrm{~mm}$ in February. This necessitated irrigation throughout the year. The mean annual maximum and minimum temperature were $32.4^{\circ} \mathrm{C}$ and $16.8^{\circ} \mathrm{C}$ with extreme lowest at $10.2^{\circ} \mathrm{C}$ in June and December and highest at $37.7^{\circ} \mathrm{C}$ in February.

\section{Experimental design}

The experiment was laid out in completely randomised design (CRD) at the green house while in the field RCBD was used. The two experiments were replicated three times. Ten clones irradiated in bulk at $15 \mathrm{~Gy}$ from $\mathrm{Co}^{60}$ gamma source were used. Control used was clone that was not irradiated, although passed through four cycles in tissue culture. The plot sizes in the field measured $1 \mathrm{~m}$ x $3 \mathrm{~m}$. Plant spacing was $1 \mathrm{~m}$ within the rows and $1 \mathrm{~m}$ between the rows. 10 clones including unirradiated one were used in the experiment. The clones were obtained from the green house and included unirradiated control

\section{Establishment of in vitro plantlets}

Irradiated plantlets were subcultured for 4 culture cycles to eliminate chimera, before the start of this experiment. The plantlets were ready for subculture after six weeks. Growth media used was (MS) (Murashige and Skooge, 1962) formulation basal medium supplemented with Thiamine, Myoinosital, Benzyl-Amino- Purine, NAA, GA 3 , Sucrose and B5. Agar was used as the gelling agent. The last culture at M1V4 were transplanted to the greenhouse and allowed to grow for 1 month 


\section{Dna isolation}

DNA extraction was done from fresh leaves from the plants growing the green house using the Dela Porter method.

\section{Polymerase chain reaction}

Simple Sequence Repeats (SSR) amplification reaction was performed in $25 \mu$ l volumes containing10ng of template DNA, 1.0ng of each primer, $0.2 \mathrm{mM}$ of each $\mathrm{dNTP}, 2.5 \mathrm{mM} \mathrm{Mgcl}_{2}, 1$ unit of Taq DNA polymerase (promega). The conditions of amplification were as follows; Initial denaturation was $94^{\circ} \mathrm{C}$ for $5 \mathrm{Min} .35$ cycles of denaturizing at $94^{\circ} \mathrm{C}$ for 30s; optimal annealing temperature ranged from $5^{\circ} \mathrm{C}$ to $55.5^{\circ} \mathrm{C}$ for 1 Min Primer extension at $72^{\circ} \mathrm{C}$ for $10 \mathrm{~min}$; and a single extension at $72^{\circ} \mathrm{C}$ for $10 \mathrm{~min}$ (Gavin et al., 2018) Amplified products were seperated according to size using high resolution agarose gels at $4 \%$ run at $100 \mathrm{v}$ for $3 \mathrm{~h}$ and stained with ethidium bromide. Gels were scored using Kodak Digital science TM 1D Image Analysis software (Version2.0.1), and the sizes of the amplified fragments were determined by comparison with a $100 \mathrm{bp}$ ladder.

\section{Characterisation of mutagenised seedlings population in the green house and field}

Potted putative seedlings were characterised in the green house until 1 month of growth. Data Collected included plant height, number of nodes, leaf morphology (number of leaf lobes) and colour of petiole. The data was collected after every fortnight. The field evaluation of the mutagenised population included plant height, number of branches and colour of petiole and leaf morphology and data was collected for 6 months.

\section{Genetic polymorphism of mutagenised population}

Polymorphism was determined by the number of bands scored from the autoradiograph photos of the gels where DNA was extracted, amplified in PCR.

\section{Results and discussion}

For each of the determined growth disease variation parameters, analysis of variance (ANOVA) was computed, and where significance F-values $(\mathrm{P}<0.05)$ existed, means separation were done using the Least Significant Difference (LSD) Cassava has been described as a shrubby perennial crop that grows to a height of up to 2-3 metres. The mature stem is woody, cylindrical and formed by alternating nodes and internodes. On the nodes of the oldest parts of the stem, are protuberances which are the scars left by the plants first leaves. The large compound, dark green, reddish veined leaves are palmately divided into about three, five, six, seven or even eight leaflets (lobes). The stems contain soft white pith and have nodes from which new plants are obtained. It is the differences in these parameters that lead to classification of the different cassava varieties. Breeders use this variation to separate the different varieties.

\section{Results from this study are presented in Table 1 and Figures 1 to 4}

\section{Genetic polymorphism using ssr markers}

Figure 1 shows the PCR product after priming with one of the 10 SSR markers used in the experiment

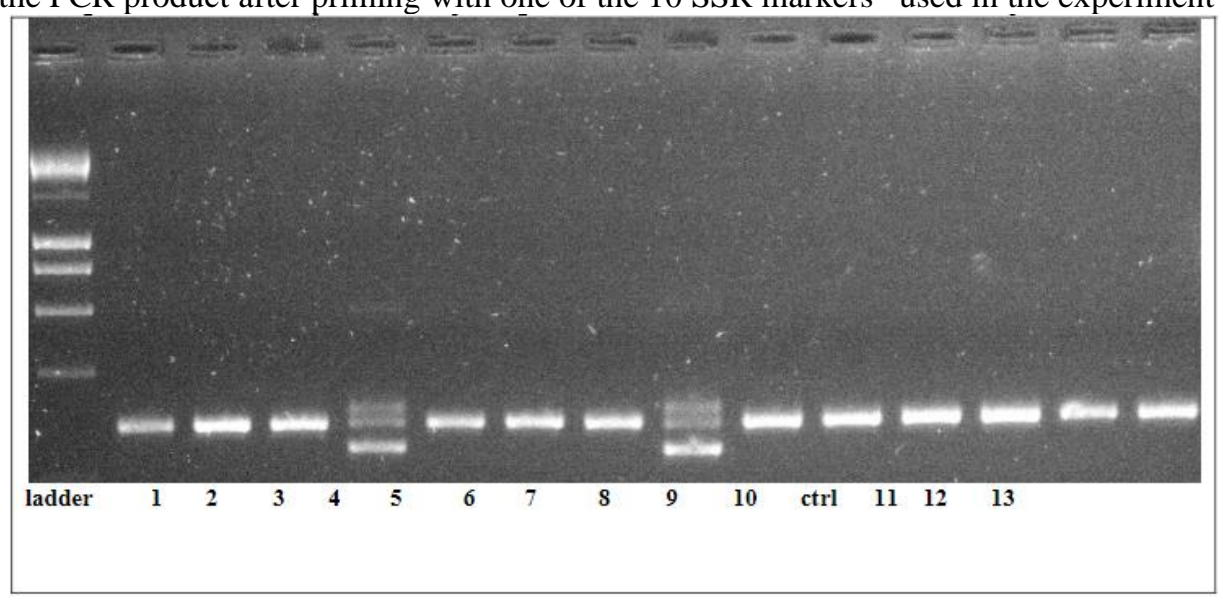

Fig 1: PCR product after running of the gel for 1 of the SSR primers

Table 1 shows the results obtained on plant height, leaf morphology, petiole colour and the number of nodes from the mutant population selected. The selections differed significantly from each other, with clone 4 having the highest plant height but among the lowest number of nodes. This indicates that the internodes for this clone were relatively widely spaced. Selection 7 was short and had the fewest number of nodes. This indicates that the internodes for this selection was the smallest. Selection 8 had very few nodes but significantly more than those for selection 7 while the height was not significantly different for the two selections. This impliesthat the internodes for selection 8 were even shorter than for selection number 7 . The petiole colour for the two was not significantly different,at 3.33 and 4 , although 7 would be classified as greenish red,while 8 would be seen as red. The number of the lobes for all selections but 6 and 9 averaged 5 and thus were not different. Only selections 6 and 9 had differing number of lobes,at 3 in number. 
he parent variety had fewer nodes than clone 8 but more than clone 7and 4 . This means that there was diversity in these selection, both among themselves, and when compared with their parent. The control had reddish green petioles, similar to 4 and 7 , while 8 and 9 had red petioles.

Table 1: Plant heights, Number of lobes, Number of nodes and petiole colour for 10 mutant and 1 parent clones

\begin{tabular}{|l|l|l|l|l|}
\hline Clone code & HEIGHT & LOBES & NODES & P. COLOUR \\
\hline 1 & $84.00 \mathrm{~b}$ & $5.00 \mathrm{a}$ & $20.00 \mathrm{c}$ & $4.00 \mathrm{a}$ \\
2 & $54.66 \mathrm{c}$ & $5.00 \mathrm{a}$ & $24.00 \mathrm{a}$ & $3.00 \mathrm{ab}$ \\
3 & $31.00 \mathrm{~d}$ & $5.00 \mathrm{a}$ & $12.00 \mathrm{i}$ & $3.00 \mathrm{ab}$ \\
4 & $113.00 \mathrm{a}$ & $5.00 \mathrm{a}$ & $23.00 \mathrm{~b}$ & $3.00 \mathrm{ab}$ \\
5 & $90.66 \mathrm{~b}$ & $5.00 \mathrm{a}$ & $18.00 \mathrm{~d}$ & $3.33 \mathrm{ab}$ \\
6 & $26.00 \mathrm{de}$ & $3.00 \mathrm{~b}$ & $14.00 \mathrm{~g}$ & $4.00 \mathrm{a}$ \\
7 & $16.00 \mathrm{e}$ & $5.00 \mathrm{a}$ & $11.00 \mathrm{j}$ & $3.33 \mathrm{ab}$ \\
8 & $24.00 \mathrm{de}$ & $5.00 \mathrm{a}$ & $16.00 \mathrm{e}$ & $4.00 \mathrm{a}$ \\
9 & $25.00 \mathrm{de}$ & $3.00 \mathrm{~b}$ & $16.00 \mathrm{e}$ & $4.00 \mathrm{a}$ \\
ctrl & $24.33 \mathrm{de}$ & $4.33 \mathrm{a}$ & $13.00 \mathrm{~h}$ & $3.00 \mathrm{ab}$ \\
11 & $23.66 \mathrm{de}$ & $4.33 \mathrm{~b}$ & $15.00 \mathrm{f}$ & $3.66 \mathrm{ab}$ \\
\hline C.V & & & & $\mathbf{0 . 0 0 0}$ \\
\hline LSD & $\mathbf{1 4 . 3 7 9 2 2}$ & $\mathbf{1 0 . 9 0 2 7 5}$ & $\mathbf{2 0 . 1 5 3 5}$ & $\mathbf{0 . 0 0 0}$ \\
\hline
\end{tabular}

* Means with the same letter are not significantly different.

\section{Genetic polymorphism of mutant population}

Genetic polymorphism determines genetic variation within population of plants.

Variability within a certain population can be assessed through screening for genetic polymorphism. This can be achieved using certain specific markers of interest. In this study, SSR markers were used to study the difference within the mutant population at the gene level. Fig 1 shows the mapgenerated when one of the SSR primer sets was used as a marker to demonstrate polymorphism. Of the 10 markers used 4 showed polymorphisms (Data not shown). Clone 4 and clone 8 varied from the rest of the population at the molecular level, with 3 bands each, as shown in Fig 1 . Increasing the number of SSR markers and their diversity could improve the separation of the selected clones.

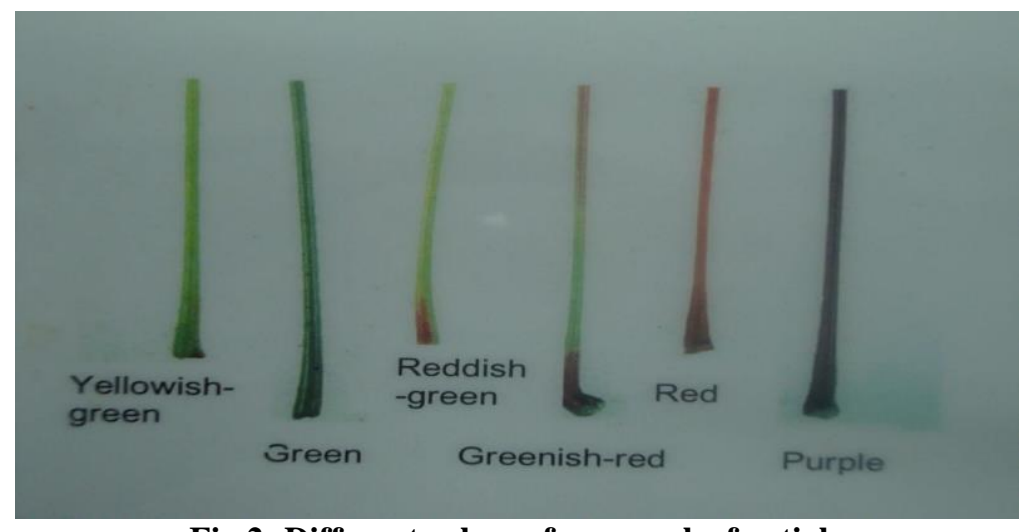

Fig 2: Different colors of cassava leaf petiole

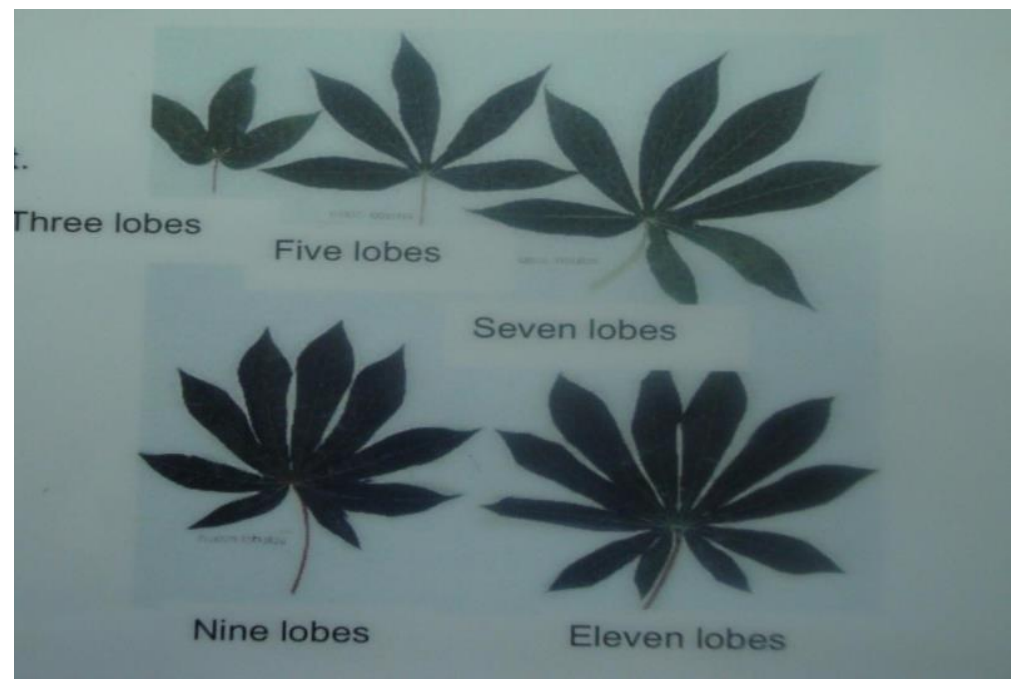

Fig 3: Cassava leaves showing the number of lobes 


\section{Effect of mutation on growth of cassava at seedling stage}

There are many different features of a plant that can be measured through observation to determine the extent of /healthy plant growth. Some of the features include Plant height, amount of nodes/ length of internodes. Difference in the rates of growth between the mutants and control were significant. Similarly, growth rates within the mutagenised clone population were significant. Height as the growth parameters used significantly varied within the mutant population and with the control. Some clones grew slower than others notably clone 7 from Table 1 growth was lower than the control. There was significant difference in growth between clones and control as well as among themselves. Increase of plant height is likewise not uniform phenomenon. It is in many crops fundamentally due to an initial increase in internode length, sometimes, accompanied by an increase in the internode number. Moreover, length of the cells is increased in some genotypes also their number per unit area (Weber and Gottschalk 1973). Tallness is generally an undesirable trait, because the stability of the stem is negatively influenced. Therefore, tall mutants are only in exceptional cases of agronomic interest. This then led to clones 3, 7 and 11 being favoured against the rest. The short internodes for these clones are also favourable.

\section{Number of nodes}

The point on the stem where leaves develop is called a node. The region between a pair of adjacent nodes is called the internode. Nodal formation patterns showed significant differences among the mutant clones. The height of the clones did not affect the number of nodes formed. This is notable since some of the shorter clones had more nodes with shorter internodes than the taller clones. Clone 2 had the highest number of nodes at 24 while clone 7 had the lowest number of nodes at 11 . The control had 13 nodes. $90 \%$ of the mutagenised population had significantly more nodes compared to the control, indicating that mutagenesis impacted on number of nodes per stem.

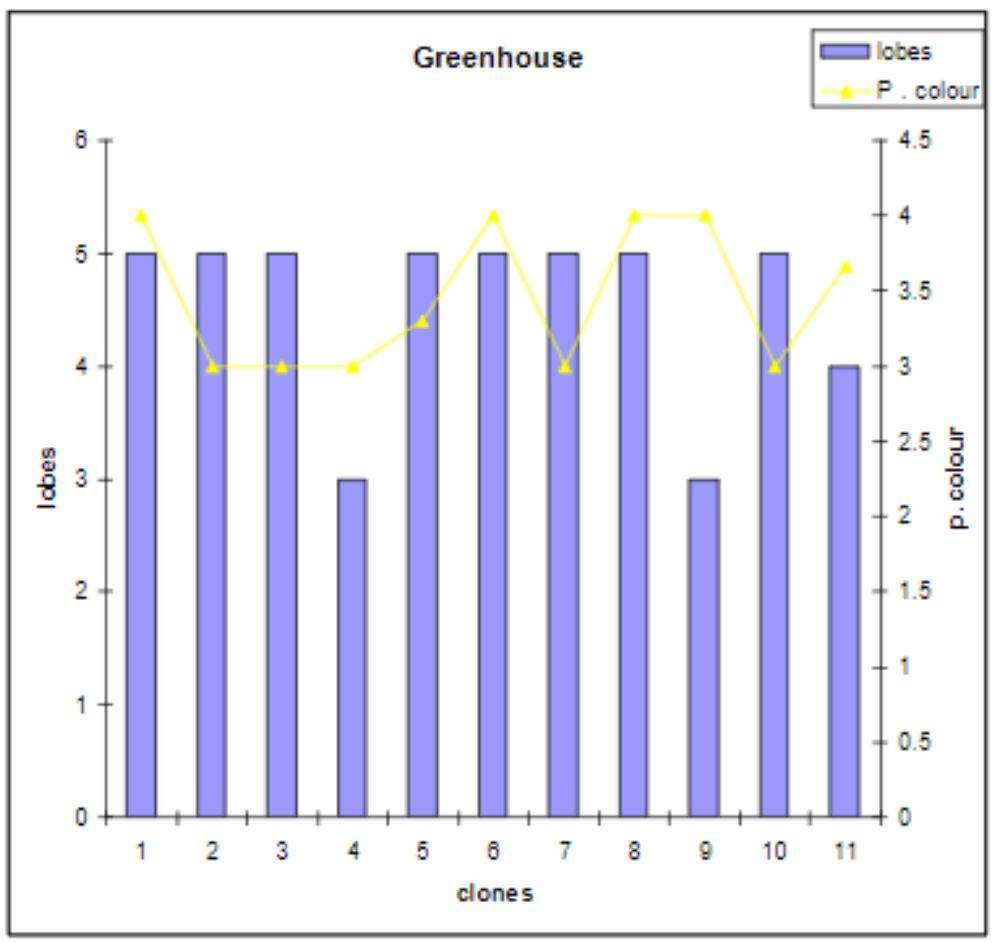

Fig 4: Plant Leaf Morphology and colour in the greenhouse

\section{Number of leaf lobes and Petiole colours}

Leaf shape and orientation can be used as a phenotypic variability feature in a particular population. Homogeneous population would exhibit similar features. The number of leaf lobes within the mutagenised population ranged between 4 lobes and 9 lobes. The control had 5 lobes. There was no significant different in colour of petiole within the mutagenised population apart from 4 and 9. These findings of the study underscore the report by Agre et al. (2016) that farmers use the colour of the stems and leaves to identify their cassava cultivars. The colours ranged from reddish green (clone 4 and 9) to red. Clones 1, 6, 8,9 and 11 had darker petioles than the parent while the rest resembled the parent (Fig 4).

\section{Conclusion and recommendation}

Selected cassava clones differed in their phenotypic and genetic characteristics indicating that mutation was effective in creating variation.

It is recommended that the variation should be further studied to exploit its usefulness in cassava improvement and production. 


\section{Acknowledgement}

Egerton University and KALRO are acknowledged for granting experimental space and administrative support. This work was partially supported by funds and equipment from International Atomic Energy Agency (IAEA).

\section{References}

[1].Agre AP, Badara G, Adjatin A, Dansi A, Bathacharjee R, Rabbi IY, Dansi M, Gedil M (2016). Folk taxonomy and traditional management of Cassava (Manihot esculenta Crantz) Diversity in Southern and Central Benin. Int J Innov Sci Res 20:500-515

[2].Andrade EKV, Andrade Júnior VC, Laia ML, Fernandes JSC, Oliveira AJM, Azevedo AM (2017). Genetic issimilarity among sweet potato genotypes using morphological and molecular descriptors. Acta Sci Agron 39:447455

[3].Dixon AGO, Ngeve JM, Nukenine EN (2002). Genotype $\times$ environment effects on severity of cassava bacterial blight disease caused by Xanthomonas axonopolis pv. manihotis. Eur J Plant Pathol 108(8):763-770

[4].Gavin Lear, Ian Dickie, Jonathan Banks, Stéphane Boyer, Hannah Buckley, (2018). Methods for the extraction, storage, amplification and sequencing of DNA from environmental samples. New Zealand Journal of Ecology, The New Zealand Ecological Society, 2018, 42, pp.0 - 0. ff10.20417/nzjecol.42.9ff. ffhal-02302242f

[5].Kariuki,C.W.,J.W. Kamau, J. Mbwika, A.O. Makhao, S.Wambugu, T.Tunje, Gatheru, Njaimwe, Kwach, Wambua M.Odendo, M.Lutta and E.G.Karuri, (2002). A report on cassava subsector analysis for Kenya. Proceeding of the regionalworkshop on improving cassava subsector, Nairobi, Kenya.April 2002:35-42

[6].Kinyua, M.G., H Okwaro, (2021). Effect of Gamma Irradiation Mutagenesis on Diversity of Cassava Tissue Culture Plantlets. International Journal of Scientific and Engineering Research. Vol 12 Issue 2, February 2021

[7].Nassar, N.M.A (1978) Wild manihot bspecies of central Brazil for cassava breeding: can.j.plant.sc.58:257-261

[8].Temegne NC, Ajebesone FN, Kuate AF (2015). Influence of soil chemical composition on nutrient content and yield of cassava (Manihot esculenta Crantz, Euphorbiaceae) in two agro-ecological zones of Cameroon. Int J Biol Chem Sci 9:2776-2788

[9].Weber E,Gottschalk W 1973 Die Beziehungen Zwischen: Zellgrobe und internodienlange bei strahleninduzierten Pisum';mutanten. Beitr Biol pfl49:101-126

[10]. Williams, J.G.K.; M.K.Hanafey; J.A.Rafalski; S.V.Tingey.1990. DNA Polymorphism amplified by arbitrary primers are useful as genetic markers. Nucleic Acids RES.18: 6531-6535. 